\title{
Tolerance Induced by Physiological Levels of Secreted Proteins in Transgenic Mice Expressing Human Insulin
}

\author{
Phyllis Jonas Whiteley, ${ }^{\star}$ Jeffrey P. Lake," Richard F. Selden, ${ }^{\star}$ and Judith A. Kapp* \\ *Department of Pathology, The Jewish Hospital of St. Louis, and Department of Pathology and Microbiology/Immunology, \\ Washington University Medical School, St. Louis, Missouri 63110; and $\ddagger^{ \pm}$Department of Molecular Biology, Massachusetts \\ General Hospital, and Department of Genetics, Harvard Medical School, Boston, Massachusetts 02114
}

\begin{abstract}
We have used transgenic mice to study immune tolerance to autologous, non-MHC encoded proteins that are expressed at physiological levels in the circulation. The transgenic mice used in these studies express the human preproinsulin gene and synthesize human proinsulin. Human and mouse insulin are secreted from the pancreatic islets of transgenic mice in response to normal physiological stimuli, such as glucose. Our data demonstrate that the transgenic mice have acquired tolerance to human insulin. The repertoire of $T$ cells specific for exogenous antigens is shaped by the acquired tolerance to autologous proteins since pork but not beef or sheep insulin is also nonimmunogenic in the transgenic mice. We also found that the transgenic mice were tolerant to human proinsulin, the intracellular precursor of insulin. Unresponsiveness to human proinsulin most likely results from tolerance of insulin-specific and proinsulin-specific $T$ cells that recognize the secreted enzymatic cleavage products of proinsulin, insulin and C-peptide.
\end{abstract}

\section{Introduction}

Rearrangement and expression of $T$ cell receptor $(T c R)^{1}$ genes results in the development of $\mathrm{T}$ cells that recognize a seemingly infinite variety of antigens, including autologous proteins. Tolerance normally prevents $T$ cells that recognize self antigens from causing autoimmune diseases. For certain cell-surface proteins, such as: MHC class II molecules (1), the minor lymphocyte stimulatory (Mls) antigen (2), and the male antigen, $\mathrm{H}-\mathrm{Y}$ (3), tolerance is maintained by deletion of the relevant clones in the thymus. Elimination of these $T$ cell clones is feasible because all of these antigens are present on cells that are either located in or traverse through the thymus during $T$ cell ontogeny and development.

However, the mechanisms underlying tolerance to nonMHC self-proteins have been difficult to examine under physi-

Address reprint requests to Dr. Kapp, Department of Pathology, CSB-7, The Jewish Hospital of St. Louis, 216 South Kingshighway, St. Louis, MO 63110.

Received for publication 2 December 1988 and in revised form 13 July 1989.

1. Abbreviations used in this paper: CFA, complete Freund's adjuvant; PFC, plaque-forming cell; TcR, T cell receptor.

J. Clin. Invest.

(c) The American Society for Clinical Investigation, Inc. $0021-9738 / 89 / 11 / 1550 / 05 \$ 2.00$

Volume 84, November 1989, 1550-1554 ological conditions. Many experimental models of tolerance involve neonatal mice which were injected with a bolus of exogenous protein (4). Although the neonatally tolerized mice remain nonresponsive to the antigen as adults, these models cannot directly address the mechanisms of tolerance induced by physiological levels of circulating protein antigens. Our studies address the development of tolerance to self-proteins that are not cell surface molecules and are not synthesized by cells in the thymus. In the present study, we have investigated development of tolerance in transgenic mice that express the human preproinsulin gene. These mice, have been previously shown to express mRNA for human proinsulin, the precursor form of insulin, only in pancreatic islets (5). In the islets, human proinsulin is enzymatically cleaved into insulin and C-peptide, which are subsequently secreted in response to normal physiological signals (5). The transgenic mice secrete physiological amounts of insulin and C-peptide containing a mixture of both mouse and human proteins.

\section{Methods}

Mice. $\mathrm{C} 57 \mathrm{BL} / 10\left(\mathrm{H}-2^{\mathrm{b}}\right)$ and $\mathrm{BALB} / \mathrm{c}\left(\mathrm{H}-2^{\mathrm{d}}\right)$ mice were purchased from Jackson Laboratories, Bar Harbor, ME. The H-2 ${ }^{k / b}$ hybrids (B10.BR $\times$ B10)F1, (BALB.K $\times$ BALB.B)F1, and the H-2 $2^{\mathrm{d} / \mathrm{k}}($ BALB/c $\times$ CBA/ $\mathrm{N}) \mathrm{F} 1$ mice were bred in the Animal Resources Facility of the Jewish Hospital.

The transgenic mice were derived by injecting a $12.5-\mathrm{kb}$ fragment containing the human preproinsulin gene into the pronuclei of ova from $\left(\mathrm{C} 57 \mathrm{BL} / 6\left(\mathrm{H}-2^{\mathrm{b}}\right) \times \mathrm{C} 3 \mathrm{H}\left(\mathrm{H}-2^{\mathrm{k}}\right)\right) \mathrm{F} 1$ mice that had been fertilized by $(\mathrm{C} 57 \mathrm{BL} / 6 \times \mathrm{C} 3 \mathrm{H}) \mathrm{F} 1$ males $(5)$. Mice expressing the human insulin gene were identified by measuring the concentration of human C-peptide in the plasma of mice after glucose challenge (5). The transgenic mice were bred to $(\mathrm{C} 57 \mathrm{BL} / 6 \times \mathrm{C} 3 \mathrm{H}) \mathrm{F} 1$ from which we selected transgenic mice, homozygous for $\mathbf{H}-2^{\mathrm{k}}$ by $\mathbf{H}-2$ typing of their erythrocytes (6). The transgenic mice are maintained as heterozygotes for the human insulin gene and backcrossed with normal C57BL/10 $\left(\mathrm{H}-2^{\mathrm{b}}\right)$ or BALB/c $\left(\mathrm{H}-2^{\mathrm{d}}\right)$ mice to provide the $\mathrm{H}-2^{\mathrm{k} / \mathrm{b}}$ and $\mathrm{H}-2^{\mathrm{d} / \mathrm{k}}$ mice used in these studies. These transgenic mice have a random assortment of background genes; however, we have previously shown there to be no detectable effect of different background genes on responsiveness to insulin (7). Control mice for these experiments were H-2 matched nontransgenic littermates as well as $\mathrm{H}-2$ matched $\mathrm{F} 1$ hybrids between inbred strains. All mice were maintained in strict accordance with $\mathrm{NIH}$ guidelines for the care of laboratory animals.

Antigens and immunizations. Semisynthetic human insulin was a gift of John Lanphear, Squibb Co., Princeton, NJ; recombinant human insulin, proinsulin and C-peptide was a gift from Dr. Ron Chance, Eli Lilly \& Co., Indianapolis, IN. The immunological activities of semi-synthetic and recombinant human insulin were the same in all our assays, thus, they were used interchangeably in these studies. Pork insulin was purchased from Elanco, Indianapolis, IN and pork proinsulin from Squibb Novo, Princeton, NJ. Mice were injected with $50 \mu \mathrm{g}$ antigen in a 1:1 ratio with complete Freund's adjuvant (CFA) containing Mycobacterium tuberculosis H37Ra (Difco Laboratories, Detroit, MI). 
Antibody assays. Serum antibody was measured by an ELISA using beef insulin- or human proinsulin-coated plates as previously described (8). Antibodies induced by various insulins are extremely cross-reactive and no significant differences were found using beef, pork, or human insulin-coated plates. Thus, beef insulin was used throughout these experiments. Our assay detects both IgG and IgM antibodies; however we have previously shown that primary immunization of insulin elicits predominantly insulin-specific IgG and not IgM antibodies (9). Insulin-specific IgG plaque-forming cells (PFC) were detected with beef insulin-conjugated sheep erythrocytes as previously described (9). The results are expressed as the arithmetic mean \pm SEM PFC of three mice per group. Each experiment has been repeated at least three times with very reproducible results; therefore the results of representative experiments are shown.

\section{Results}

Insulin-specific tolerance in transgenic mice. Previous experiments have demonstrated that $\left(\mathrm{H}-2^{\mathrm{k}} \times \mathrm{H}-2^{\mathrm{b}}\right) \mathrm{F} 1$ mice respond to pork insulin despite the fact that the homozygous $\mathrm{H}-2^{\mathrm{k}}$ and $\mathrm{H}-2^{\mathrm{b}}$ parental strains do not $(8-11)$. The ability of the $\mathrm{F} 1$ mice to respond to pork insulin is due to transcomplementation of the alpha and beta subunits of the MHC-encoded class II molecules which form unique Ia proteins (12). Responses to human insulin, which differs from pork insulin only in the terminal amino acid of the B chain (13), have not previously been characterized; thus, we first determined that normal $\mathrm{H}-2^{\mathrm{d}}$ mice responded to human insulin, whereas $\mathrm{H}-2^{\mathrm{b}}$ and $\mathrm{H}-2^{\mathrm{k}}$ mice did not (data not shown). The transgenic $\mathrm{H}-2^{\mathrm{d} / \mathrm{k}}$ (Fig. 1) and $\mathrm{H}-2^{\mathrm{k} / \mathrm{b}}$ (Fig. 2) mice did not produce insulin-specific antibodies when injected with human insulin, whereas $\mathrm{H}-2$ identical, normal F1 mice and nontransgenic littermates did (Fig. 2). Transgenic mice were also tolerant to pork insulin (Fig. 2).

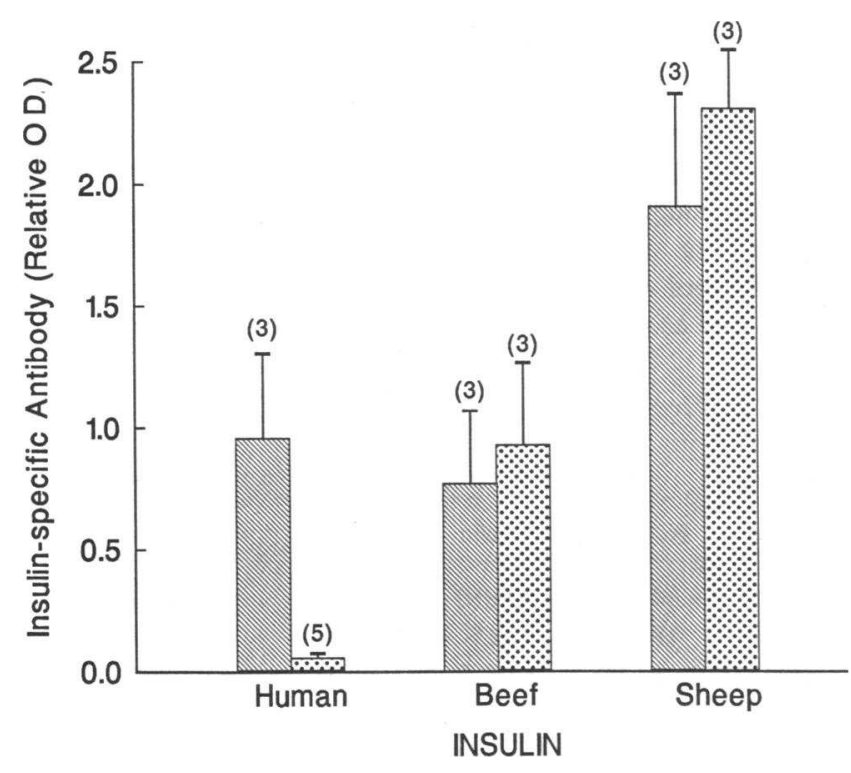

Figure 1. Primary responses to exogenous insulin in $\mathrm{H}-2^{\mathrm{d} / \mathrm{k}}$ mice. Normal (BALB/c $\times$ CBA/N)F1 (hatched bar) and H-2 matched transgenic (dotted bar) mice were injected intraperitoneally with 50 $\mu \mathrm{g}$ of human, beef, or sheep insulin in CFA. Sera were collected on day 21 and assayed for insulin-specific antibodies by ELISA. The data was normalized to a standard antibody and expressed as the relative $\mathrm{OD} \pm \mathrm{SEM}$ at a 1:100 dilution of serum. Preimmune sera from transgenic and nontransgenic mice had a relative $O D \leq 0.1$. The numbers in parentheses represent the numbers of mice per group.

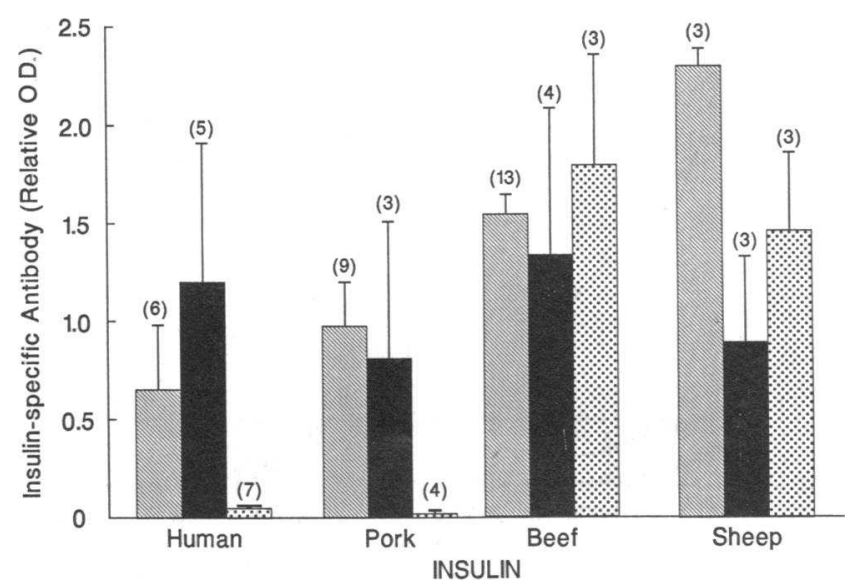

Figure 2. Primary responses to exogenous insulin in $\mathrm{H}-2^{\mathrm{k} / \mathrm{b}}$ mice. Normal (B10.BR $\times$ B10)F1 mice (hatched bar), H-2 matched nontransgenic (shaded bar), and transgenic (dotted bar) littermates were injected intraperitoneally with $50 \mu \mathrm{g}$ of human, pork, beef, or sheep insulin in CFA. Sera were collected on day 21 and assayed for insulin-specific antibodies by ELISA. The data was normalized to a standard antibody and expressed as the relative OD \pm SEM at a 1:100 dilution of serum. Preimmune sera from transgenic and nontransgenic mice had a relative OD $\leq 0.1$. The numbers in parentheses represent the numbers of mice per group.

However, the lack of an antibody response in the transgenic mice is not due to a generalized defect in the immune system, since they responded normally to beef and sheep insulin (Figs. 1 and 2). The tolerance to human insulin was not uniquely associated with a particular MHC class II antigen, as two different strains of transgenic mice gave the same results.

The kinetics of the primary antibody response to insulin were examined. Sera from normal and immune mice were assayed by ELISA for insulin-specific antibody at various times after intraperitoneal injection with human insulin. Neither nontransgenic or transgenic mice produced insulin-specific antibody in preimmune sera or after $7 \mathrm{~d}$ postinjection (Fig. 3). By day 14 the nontransgenic mice had begun to develop an immune response that was maximal by day 21 . By contrast, the transgenic mice did not produce insulin-specific antibodies at any time. In addition, no insulin-specific antibodies were induced in transgenic mice injected with human insulin and CFA in the footpad. A secondary injection of the transgenic mice with human insulin also did not elicit a response. These data demonstrate that the kinetics and the route of immunization did not effect the response. Thus, the transgenic mice display complete and long lived tolerance to human insulin.

Tolerance to human proinsulin in transgenic mice. The next issue we examined was whether transgenic mice were also tolerant to proinsulin. Proinsulin is the precursor of insulin and is composed of a single polypeptide chain containing the $A$ and $B$ chains of insulin plus a connecting peptide (C-peptide) (14). Proinsulin is enzymatically cleaved in clathrin-coated early secretory vesicles (15), producing equimolar concentrations of insulin and C-peptide, both of which are secreted. Human proinsulin elicited insulin-specific antibodies in normal $\left(\mathrm{H}-2^{\mathrm{k} / \mathrm{b}}\right)$ mice but not in the transgenic mice (Fig. $4 A$ ). Similar results were also found in $\mathrm{H}-2^{\mathrm{d} / \mathrm{k}}$ transgenic mice (Fig. $4 \mathrm{~B}$ ), again demonstrating that this effect was not unique to 


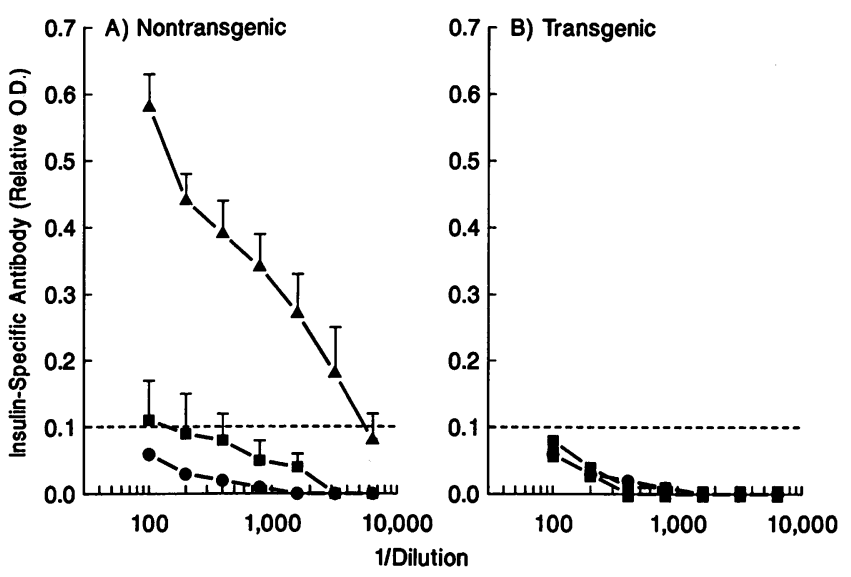

Figure 3. Kinetics of the primary antibody response. $\mathrm{H}-2^{\mathrm{b} / \mathrm{k}}$ matched nontransgenic $(A)$ and transgenic $(B)$ littermates were injected intraperitoneally with $50 \mu \mathrm{g}$ of human insulin in CFA. Sera were collected on days 7,14 , and 21 and assayed for insulin-specific antibodies by ELISA. The data was normalized to a standard antibody and expressed as the relative $\mathrm{OD} \pm$ SEM at various titers. Preimmune sera from transgenic and nontransgenic mice had a relative OD $\leq 0.1$, which is indicated by the dashed line. The SEM for all transgenic samples and day 7 of the nontransgenic samples were negligible, and thus not included.

one strain of mouse. We also examined these sera using proinsulin-coated ELISA plates. No proinsulin-specific antibodies were found in transgenic mice injected with human proinsulin, whereas sera from nontransgenic mice bound to plates sensitized with either insulin or proinsulin (Fig. 5).

Proinsulin is composed of epitopes that are shared with insulin and C-peptide, raising the possibility that tolerance to proinsulin was actually induced by insulin and/or C-peptide, which are secreted rather than the nonsecreted proinsulin. This possibility could not be investigated in the transgenic mice. However, we have previously shown that insulin-specific tolerance can be induced in responder strains of mice by intra-

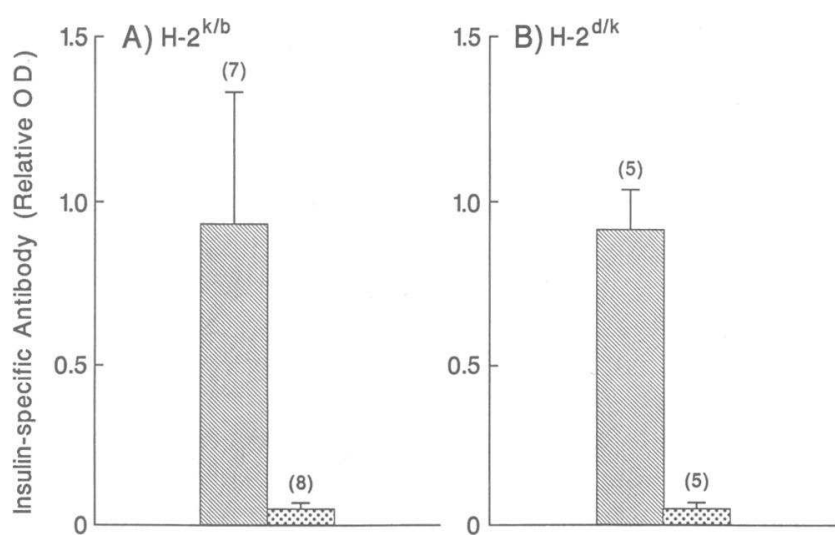

Figure 4. Primary responses to human proinsulin. Normal (hatched bar) and syngeneic transgenic (dotted bar) mice were injected intraperitoneally with $50 \mu \mathrm{g}$ human proinsulin in CFA. Sera were collected on day 21 and assayed for insulin-specific antibodies by ELISA. The data was normalized to a standard antibody and expressed as the relative OD \pm SEM at a 1:100 dilution of serum. The numbers in parentheses represent the numbers of mice per group. Normal $\mathrm{H}-2^{\mathrm{k} / \mathrm{b}}$ mice are $(\mathrm{B} 10 . \mathrm{BR} \times \mathrm{B} 10) \mathrm{F} 1(A)$ and $\mathrm{H}-2^{\mathrm{d} / \mathrm{k}}$ are $(\mathrm{BALB} / \mathrm{c} \times \mathrm{CBA} / \mathrm{N}) \mathrm{F} 1(B)$.
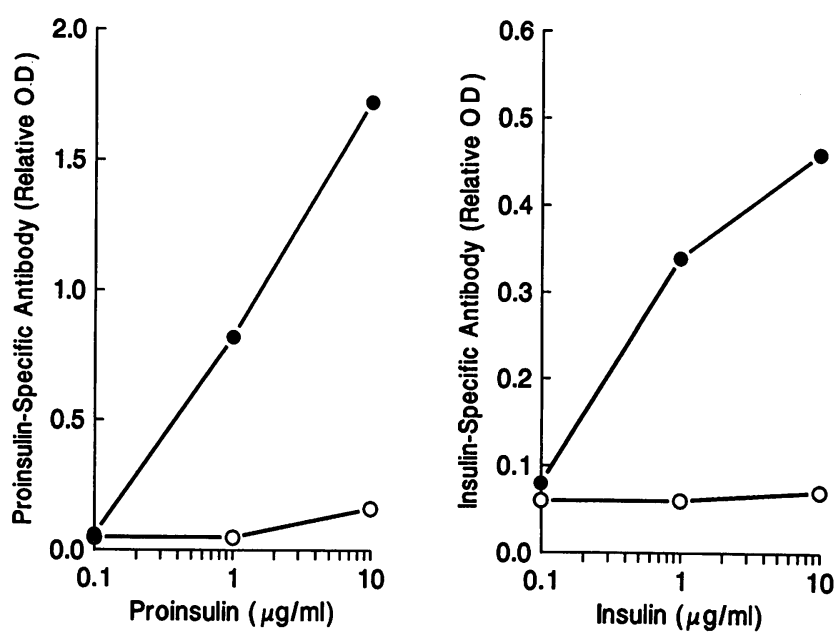

Figure 5. Proinsulin stimulates proinsulin and insulin-specific antibodies. Normal BALB/c (solid circles) and transgenic $\mathrm{H}-2^{\mathrm{k} / \mathrm{b}}$ (open circles) mice were injected intraperitoneally with $50 \mu \mathrm{g}$ human proinsulin in CFA. Sera were collected on day 21 and assayed for antibodies on ELISA plates sensitized with the indicated concentrations of human proinsulin or human insulin. The data are expressed as the relative $\mathrm{OD} \pm \mathrm{SEM}$ for a 1:100 dilution of the serum sample.

venous injection of insulin (16). Tolerance is highly antigen specific, it requires about $1 \mathrm{wk}$ to develop fully and it lasts for $\sim 4 \mathrm{wk}$ (16). Therefore, we could use this system to determine whether the secreted proteins, insulin and C-peptide, could induce tolerance to proinsulin in responder mice separately or in combination. Normal $(\mathrm{B} 10 . \mathrm{BR} \times \mathrm{B} 10) \mathrm{F} 1$ or $\mathrm{BALB} / \mathrm{c}$ mice were pretreated with an intravenous injection of human $C$ peptide, human proinsulin, human insulin, or a mixture of human insulin and C-peptide. $7 \mathrm{~d}$ later all mice were challenged with human proinsulin in CFA and the PFC response was measured (Table I). Injection of human proinsulin tolerized mice to a subsequent challenge of proinsulin $(66-82 \%$ inhibited), which confirms this model system. Insulin had a variable effect causing inhibition ranging from 18 to $75 \%$ and C-peptide had virtually no effect on responses to proinsulin. Most striking was the finding that pretreatment with the mixture of insulin and C-peptide inhibited the response to proinsulin as well as pretreatment with proinsulin.

Table I. In Vivo Tolerance to Human Proinsulin

\begin{tabular}{cllcc}
\hline & \multicolumn{4}{c}{ Percent response to proinsulin in mice pretreated with: } \\
\cline { 2 - 5 } Experiment & Proinsulin & Insulin & C-Peptide & Insulin plus C-peptide \\
\hline $1^{*}$ & $34 \pm 11$ & $82 \pm 10$ & 100 & N.D. \\
$2^{\ddagger}$ & $18 \pm 12$ & $25 \pm 5$ & $70 \pm 6$ & $7 \pm 3$ \\
$3^{*}$ & $18 \pm 4$ & $44 \pm 15$ & 100 & $26 \pm 4$
\end{tabular}

Normal (BALB.K $\times$ BALB.B)F1 (experiment 1) or BALB/c (experiments 2 and 3) mice were injected with PBS (control) or $100 \mu \mathrm{g}$ human proinsulin, insulin, $\mathrm{C}$-peptide, or both insulin and C-peptide. After $7 \mathrm{~d}$, all mice were challenged in the footpad with $50 \mu \mathrm{g}$ of human proinsulin in CFA. $14 \mathrm{~d}$ later, lymph nodes were assayed for insulin-specific PFC responses. The data is expressed as the percentage of the control response \pm SEM to proinsulin after PBS pretreatment. Control responses range from 559 to 1,238 PFC per $10^{6}$ cells.

* Three mice per group.

‡ Five mice per group. 


\section{Discussion}

The data in this report demonstrate that transgenic mice, which have circulating physiological concentrations of human insulin, are tolerant to human insulin; whereas $\mathrm{H}-2$ identical, inbred strains and nontransgenic littermates are not. The lack of an antibody response in the transgenic mice is not due to a generalized defect in the immune system, since they responded normally to beef and sheep insulin. These observations provide direct evidence to support the hypothesis that under physiological conditions, tolerance to circulating self-proteins is acquired. Transgenic mice were also tolerant to pork insulin, suggesting that the repertoire of $T$ cells specific for exogenous antigens is shaped by acquired tolerance to autologous proteins. Furthermore, acquired tolerance was not uniquely associated with a particular MHC class II antigen, as two different strains of transgenic mice gave the same results. Because the strains of mice used as recipients of the transgene normally produce insulin-specific antibodies in response to human insulin, the transgenic mice clearly express Ia antigens that can properly associate with human insulin. The transgenic mice also have the appropriate genes to produce $\mathrm{T}$ cell receptors expressing $\mathrm{V} \alpha$ and $\mathrm{V} \beta$ segments, which can bind a complex of processed human insulin in association with Ia antigens because the recipients of the insulin gene have $T$ cells that do so. Thus, acquired tolerance involves functional attenuation of the $T$ cells specific for human insulin. Furthermore, only the $T$ cells and not the B cells from transgenic mice are tolerant to human insulin (manuscript in preparation).

Our experiments also were designed to examine immune responsiveness to human proinsulin. Development of an antibody response to an autologous organ-specific, intracellular protein such as proinsulin would be expected if sequestered antigens fail to tolerize $T$ cells with the appropriate receptors. If this were true, then the transgenic mice should develop a normal immune response to human proinsulin, but they did not. Tolerance to proinsulin might be induced by the very small amount of proinsulin that reaches the circulation which has been estimated at $1-5 \%$ of the level of insulin (17). However, proinsulin is composed of epitopes that are shared with insulin and C-peptide, both of which are secreted proteins raising the possibility that tolerance to proinsulin was induced by the secreted fragments of proinsulin. Our experiments demonstrated that neither C-peptide nor insulin alone could induce the same degree of tolerance to human proinsulin as achieved by pretreatment with proinsulin in nontransgenic mice. However, when both were administered together, tolerance was virtually complete. The simplest interpretation of these results is that proinsulin stimulates insulin-specific and C-peptide specific helper $T$ cells, either one of which can interact with B cells in the development of an antibody response to proinsulin. If the helper $T$ cells are in excess, then loss of one or the other population of helper $\mathrm{T}$ cells would not signifcantly diminish the antibody response, whereas loss of both sets would abrogate the response. These results suggest that tolerance to proinsulin in transgenic mice is most likely induced by the combined effects of the secreted insulin and Cpeptide.

Tolerance has been reported for a cell-surface antigen in transgenic mice bearing an allogeneic class II MHC antigen fused to the rat insulin promotor (18). Although the transgenic I-E antigen was synthesized only in the beta cells of the pan- creas and the kidney, the recipient mice were tolerant to the I-E antigens of the donor haplotype as measured in a mixed lymphocyte response. This data and ours demonstrate that antigens that are not expressed by cells in the thymus can, nevertheless, induce tolerance; however, the mechanism responsible remains to be determined. Like tolerance to MHC class II, Mls, and $\mathrm{H}-\mathrm{Y}$ antigens, tolerance to these antigens also could be mediated by clonal deletion in the thymus; but if so, it is a very sensitive process as only very small quantities of these proteins enter the circulation and ultimately reach the thymus. Alternatively, the clones of $T$ cells which recognize these antigens might not be deleted in the thymus as we have shown to be the case for mouse insulin-specific helper $T$ cells $(19,20)$. Autoimmune disease could still be averted if such autoreactive $T$ cells are rendered anergic (21-23) or held in check by suppressor $T$ cells $(11,19,20,24,25)$. The transgenic mice expressing human insulin provide a model system for determining the physiological mechanisms responsible for induction and maintenance of self-tolerance. If gene therapy is going to be used to correct genetic abnormalities, it will be important to have such models to study the immunological consequences of expressing foreign genes before such therapy is tried in humans.

\section{Acknowledgments}

We thank Dr. Ron E. Chance, Eli Lilly, for the generous gifts of purified recombinant human insulin, proinsulin, and C-peptide as well as his continued interest in our work; Mr. John Lanphear, Squibb Novo, for the generous gift of semi-synthetic human insulin; Dr. Ron Gingerich, Washington University, for human C-peptide determinations; Drs. Vera Hauptfeld, Miro Hauptfeld, and Donald Shreffler, Washington University Medical School, for H-2 typing reagents.

This work was supported by the U. S. Public Health Service grants AI-13987 and 2 P60 DK20 S79-12, from the National Institutes of Health.

\section{References}

1. Kappler, J. W., N. Roehm, and P. Marrack. 1987. T cell tolerance by clonal elimination in the thymus. Cell. 49:273-280.

2. Kappler, J. W., U. Staerz, J. White, and P. Marrack. 1988. Self-tolerance eliminates T cells specific for Mls-modified products of the major histocompatibility complex. Nature (Lond.). 332:35-40.

3. Kisielow, P., H. Bluthmann, U. D. Staerz, M. Steinmetz, and H. von Boehmer. 1988. Tolerance in T-cell-receptor transgenic mice involves deletion of nonmature $\mathrm{CD}^{+} 8^{+}$thymocytes. Nature (Lond.). 333:742-746.

4. Siskind, G. 1984. Immunogic Tolerance. In Fundamental Immunology. W. E. Paul, editor. Raven Press, New York. 537-558.

5. Selden, R. F., M. J. Skoskiewicz, K. B. Howie, P. S. Russell, and H. M. Goodman. 1986. Regulation of human insulin gene expression in transgenic mice. Nature (Lond.). 321:525-528.

6. Stimpfling, J. H. 1961. The use of PVP as a developing agent in mouse hemagglutination tests. Transplant. Bull. 27:109-111.

7. Kapp, J. A., and D. S. Strayer. 1978. H-2 linked Ir gene control of antibody responses to porcine insulin. I. Development of insulinspecific antibodies in some but not all nonresponder strains injected with proinsulin. J. Immunol. 121:978-982.

8. Jensen, P. E., C. W. Pierce, and J. A. Kapp. 1984. Regulatory mechanisms in immune responses to heterologous insulins. II. Suppressor $T$ cell activation associated with nonresponsiveness in $\mathrm{H}-2^{\mathrm{b}}$ mice. J. Exp. Med. 160:1012-1026.

9. Jensen, P. E., and J. A. Kapp. 1984. Regulatory mechanisms in 
the immune response to heterologous insulins. I. Requirements for generation of in vitro PFC responses. Cell. Immunol. 87:73-84.

10. Keck, K. 1977. Ir gene control of carrier recognition. III. Cooperative recognition of two or more carrier determinants on insulins of different species. Eur. J. Immunol. 7:811-816.

11. Jensen, P. E., and J. A. Kapp. 1985. Genetics of insulin-specific helper and suppressor $\mathrm{T}$ cells in nonresponder mice. J. Immunol. 135:2990-2995.

12. Reske-Kunz, A. B., and E. Rude. 1982. Fine specificity of a T cell line reactive to bovine insulin. J. Immunol. 128:1252-1255.

13. Dayhoff, M. O. 1972. Atlas of Protein Sequence and Structure. National Biomedical Research Foundation, Washington, DC. 5:208.

14. Chance, R. E. 1972. Amino acid sequences of proinsulins and intermediates. Diabetes. 21(Suppl. 2):461-467.

15. Steiner, D. F., J. Michael, R. Haughten, M. Mathieu, P. R. Granner, M. Ravazzola, and L. Orci. 1987. Use of a synthetic peptide antigen to generate antisera reactive with a proteolytic processing site in native human proinsulin: demonstration of cleavage within clathrin-coated (pro)secretory vesicles. Proc. Natl. Acad. Sci. USA. 84:6184-6188.

16. Robbins, P. F., J. W. Thomas, P. E. Jensen, and J. A. Kapp. 1984. Insulin-specific tolerance induction. I. Abrogation of helper $T$ cell activity is controlled by H-2-linked Ir genes. J. Immunol. 132:4349.

17. Hartling, S. G., B. Dinesen, A.-M. Kappelgard, O. K. Faber, and C. Binder. 1986. ELISA for human proinsulin. Clin. Chim. Acta. 156:289-298.

18. Lo, D., L. C. Burkly, G. Widera, C. Cowing, R. A. Flavell, R. D. Palmiter, and R. L. Brinster. 1988. Diabetes and tolerance in trans- genic mice expressing Class II MHC molecules in pancreatic beta cells. Cell. 53:159-168.

19. Jensen, P. E., and J. A. Kapp. 1985. Stimulation of helper T cells and dominant suppressor $\mathrm{T}$ cells that recognize autologous insulin. J. Mol. Cell. Immunol. 2:133-139.

20. Whiteley, P. J., P. E. Jensen, C. W. Pierce, A. F. Abruzzini, and J. A. Kapp. 1988. Helper T-cell clones that recognize autologous insulin are stimulated in nonresponder mice by pork insulin. Proc. Natl. Acad. Sci. USA. 85:2723-2727.

21. Lamb, J. R., B. J. Skidmore, N. Green, J. M. Chiller, and M. J. Feldmann. 1983. Induction of tolerance in influenza virus-immune $T$ lymphocyte clones with synthetic peptides of influenza hemaglutinin. J. Exp. Med. 157:1434-1447.

22. Jenkins, M. K., and R. H. Schwartz. 1987. Antigen presentation by chemically modified splenocytes induces antigen-specific $\mathrm{T}$ cell unresponsiveness in vitro and in vivo. J. Exp. Med. 165:302-319.

23. Morahan, G., J. Allison, and J. F. A. P. Miller. 1989. Tolerance of Class I histocompatibility antigens expressed extrathymically. $\mathrm{Na}$ ture (Lond.). 339:622-624.

24. Gibson, J., A. Basten, K. Z. Walker, and R. H. Loblay. 1985. A role for suppressor $\mathrm{T}$ cells in induction of self-tolerance. Proc. Natl. Acad. Sci. USA. 82:5150-5154.

25. Kelly, C. J., M. D. Clayman, and E. G. Neilson. 1986. Immunoregulation in experimental interstitial nephritis: immunization with renal tubular antigen in incomplete Freund's adjuvant induces major histocompatibility complex-restricted $\mathrm{OX}^{+}$suppressor $\mathrm{T}$ cells which are antigen-specific and inhibit the expression of disease. J. Immunol. 136:903-907. 